\title{
分離型解法に基づく浅部地盤の地震動増幅に及ぼす 深部地盤の影響と改良計算法の検証 \\ EFFECTS OF DEEP SUBSURFACE STRUCTURE ON GROUND MOTION AMPLIFICATION IN SHALLOW SUBSURFACE STRUCTURE AND VERIFICATION OF AN IMPROVED NUMERICAL METHOD BASED ON THE SUBSTRUCTURE METHOD
}

\author{
永野正行* \\ Masayuki NAGANO
}

\begin{abstract}
Site amplification in the shallow subsurface structure is an important factor in strong ground motion prediction. Surface ground motions are typically evaluated using the conventional substructure method by modeling only the shallow part of the subsurface structure using ground motions on an outcropped engineering bedrock as input motions. However, this approach yields inaccurate results because the coupling effect between the shallow and deep soil layers is ignored. The error becomes large when the thickness of the deep soil layer is small and the thickness of the shallow soil layer is large because of the difference in the travel time of waves reflected from the boundary of the seismic bedrock. A rigorous method for incorporating the coupling effect with the deep subsurface structure using velocity convolution integrals is proposed and verified for both linear and strongly nonlinear shallow soil layers.
\end{abstract}

Keywords : Site amplification, Shallow subsurface structure, D eep subsurface structure, Substructure method, F DE index, Nonlinear 地盤増幅, 浅部地盤, 深部地盤, 分離型解法, FDE 指標, 非線形

\section{1. はじめに}

建物の耐震性評価や耐震設計を進めるうえで，当該敷地での地盤 増幅特性を精度良く反映させた地震動を評価することは重要となる。 近年では，計算機環境の急速な発展を背景に，震源断層の破壊から 当該地点における非線形挙動を含む地盤増幅特性までを考慮した強 震動評価が，高精度でかつ多数点を対象に行われるようになってき ている。この過程では計算手法自体の検証(Verification)が不可欠とな る。最近では, 強震動計算手法のベンチマークテストとして理論的 手法，数值計算手法，統計的グリーン関数法を取り上げ，各手法の 検証も行われている例えば1)。強震動評価のうち, 浅部の表層地盤（以 降, 「浅部地盤」と記す。）での地震動増幅は, 大地震時の建物への 入力地震動の大きさを考えるうえで重要となる例えは2)。例えば, 2011 年東北地方太平洋沖地震 $\left(\mathrm{M}_{\mathrm{W}} 9.0\right)$ の際にも, 東京湾沿岸部で周期 1.5 〜3.5 s の地震動成分が増幅したことが示されており ${ }^{3)}$, この原因の 一つとして非線形挙動を含む浅部地盤の影響が指摘されている ${ }^{4)}$ 統計的グリーン関数法もしくは数值計算法とのハイブリッド法な どを利用して地表位置での強震動を評価する際には, Fig.1(a)に示す ように, $\mathrm{S}$ 波速度が約 $400 \mathrm{~m} / \mathrm{s}$ 以上の解放工学的基盤で一度地震動を 算定する。その上の浅部地盤については, 重複反射理論に基づく等 価線形手法(例えば, $\mathrm{SHAKE}^{5}$ )等によって 1 次元場での増幅を評価 するアプローチが一般的に行われている。以降, これを「分離型解
法」と呼ぶ。一方, S 波速度が約 $3000 \mathrm{~m} / \mathrm{s}$ 以上の地震基盤より浅く, 工学的基盤より深い表層地盤(以降,「深部地盤」)に関し, Fig.1(b)に 示す浅部地盤と一体化した計算（以降，「一体型解法」）とは異なる

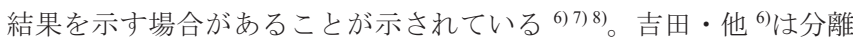
型解法で計算解の精度を上げるためには，一体型解法で得られた入 射上昇波を利用する必要があることを示した。小林・儘田 ${ }^{8)}$ は浅部 地盤を平均物性もしくは工学的基盤の一様地盤に置換することによ り，分離型解法による計算精度の向上を試みた。田中・他 ${ }^{9}$ は, 一 度線形解析により地表面で評価した地震動を剥ぎ取ることにより, 深部地盤との連成効果がある程度保持されることを示した。しかし ながらこれらは全て近似解法である。また入力する地震動が小さい 振幅レベルでも浅部地盤が非線形挙動を呈するケースが多いことか ら，より一般性を有する時間領域での応答計算手法が必要となる。

本研究では水平成層地盤の 1 次元波動場を対象に, 深部地盤が浅 部地盤での地震動増幅に与える影響を評価するとともに，その改良 計算法を提案し検証する。最初に, 浅部地盤, 深部地盤の厚さやイ ンピーダンス比等を変化させることにより, 分離型解法の計算精度 を定量的に評価する。次に, 浅部地盤の応答解析で深部地盤との連 成効果を取り入れる厳密解として, 底面境界部で深部地盤の影響を 速度合成積を用いて評価する分離型解法を提示し，その計算精度を 検証する。 


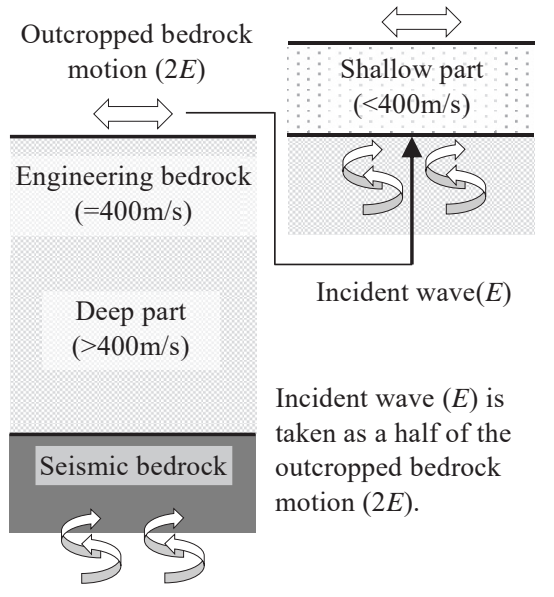

(a) Substructure method

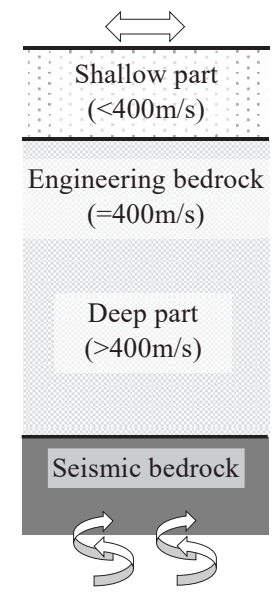

(b) Full method

Fig. 1 Two methods to evaluate 1-D amplification of soil.

\section{2. 分離型解法による計算精度評価の一例}

分離型解法の計算精度を確認するために, 大阪平野の地盤構造 ${ }^{12)}$ を参考に Table 1 に示寸地下構造を設定し, 一次元の波動伝播解析 を行った。分離型解法で基準とする工学的基盤面は表中第 4 層の上 面とする。解析は, オリジナルのモデルの他, 大阪平野における堆 積層の厚さが場所によって大きく変化することから, 工学的基盤か ら地震基盤までの厚さ $\mathrm{H}_{2}=1400 \mathrm{~m}$ の深部地盤を, 各層の層厚比を一 定として, $1000 \mathrm{~m}, 600 \mathrm{~m}, 200 \mathrm{~m}$ に圧縮したそれぞれのモデルの計 4 つで行った。減衰定数は, 神戸市中心部の深部, 浅部地盤を対象 とした地震動のシミュレーション解析結果 ${ }^{10) 11)}$ に基づき, 履歴型で $\mathrm{h}=7.5 / \mathrm{N}_{\mathrm{s}}{ }^{12)}$ とした。ただし, Vs はせん断波速度 $(\mathrm{m} / \mathrm{s})$ である。低速度 層では減衰定数がやや大きめに評価されるが, 鉛直アレー記録に基 づく検討では $\mathrm{S}$ 波速度が小さいほど減衰定数が大きく評価されてい る ${ }^{11)}$ ことを勘案し，本検討では統一的に上記で設定した。

分離型解法と精算解である一体型解法による地震基盤面から地表 までの伝達関数を Fig. 2 に比較する。分離型解法では深部地盤と浅 部地盤による伝達関数を掛け合わせて求めた。横軸の振動数は, 浅 部地盤の平均 $\mathrm{S}$ 波速度と厚さから, $1 / 4$ 波長則で計算される浅部地 盤の 1 次卓越振動数 $\mathrm{f}_{1}(\mathrm{~Hz})$ で基準化して示した。

分離型解法による各ピーク振動数や増幅倍率は一体型解法とずれ ており, 特に増幅倍率のずれは $\mathrm{f} / \mathrm{f}_{1}=1$ 前後で顕著に見られる。また $\mathrm{H}_{2}=200 \mathrm{~m}$ の深部地盤の層厚が小さくなるケースでは, 両者の差異

Table 1 Soil profile referred from subsurface structure in Osaka Plane.

\begin{tabular}{|c|c|c|c|c|}
\hline No. & $\begin{array}{c}\text { Shear } \\
\text { wave } \\
\text { velocity } \\
\mathrm{V}_{\mathrm{S}}(\mathrm{m} / \mathrm{s})\end{array}$ & $\begin{array}{l}\text { Density } \\
\rho\left(\mathrm{t} / \mathrm{m}^{3}\right)\end{array}$ & $\begin{array}{l}\text { thickness } \\
D(\mathrm{~m})\end{array}$ & Classification \\
\hline 1 & 100 & 1.7 & 15 & \multirow{3}{*}{ Shallow part } \\
\hline 2 & 200 & 1.8 & 25 & \\
\hline 3 & 300 & 1.8 & 20 & \\
\hline 4 & 500 & 1.8 & 350 & Engineering bedrock \\
\hline 5 & 600 & 1.9 & 250 & \multirow{3}{*}{$\begin{array}{l}\text { Deep part } \\
\text { (thickness is } \\
\text { proportionally varied) }\end{array}$} \\
\hline 6 & 800 & 2.0 & 250 & \\
\hline 7 & 1000 & 2.1 & 550 & \\
\hline 8 & 3200 & 2.7 & - & Seismic bedrock \\
\hline
\end{tabular}

が大きく現れている。

次に地震基盤から最大振幅 1 で中心周期 1 秒のリッカー波をパル ス波として入力し，地表面で応答波形を比較した。この結果を Fig.
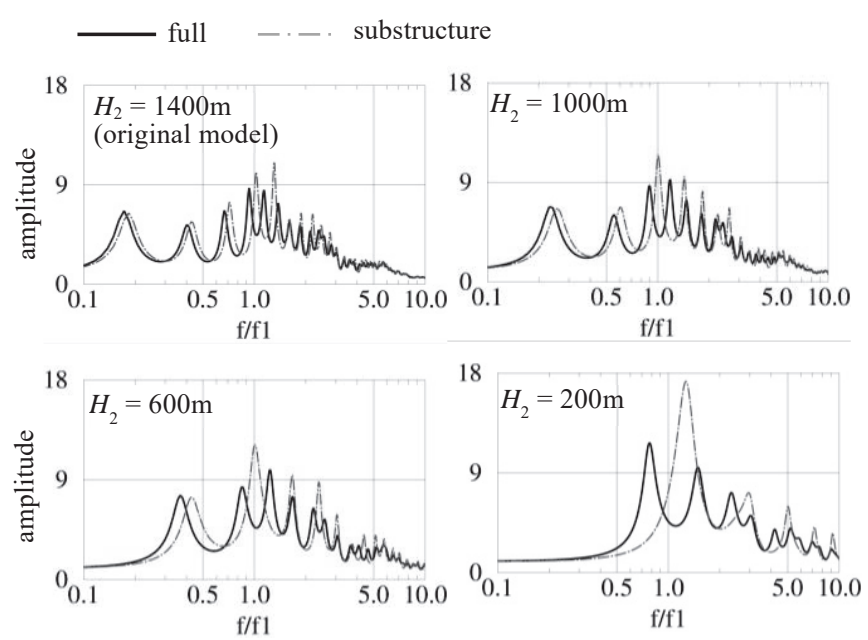

Fig. 2 Comparison of transfer functions by full and substructure methods for various thickness of deep subsurface structures.
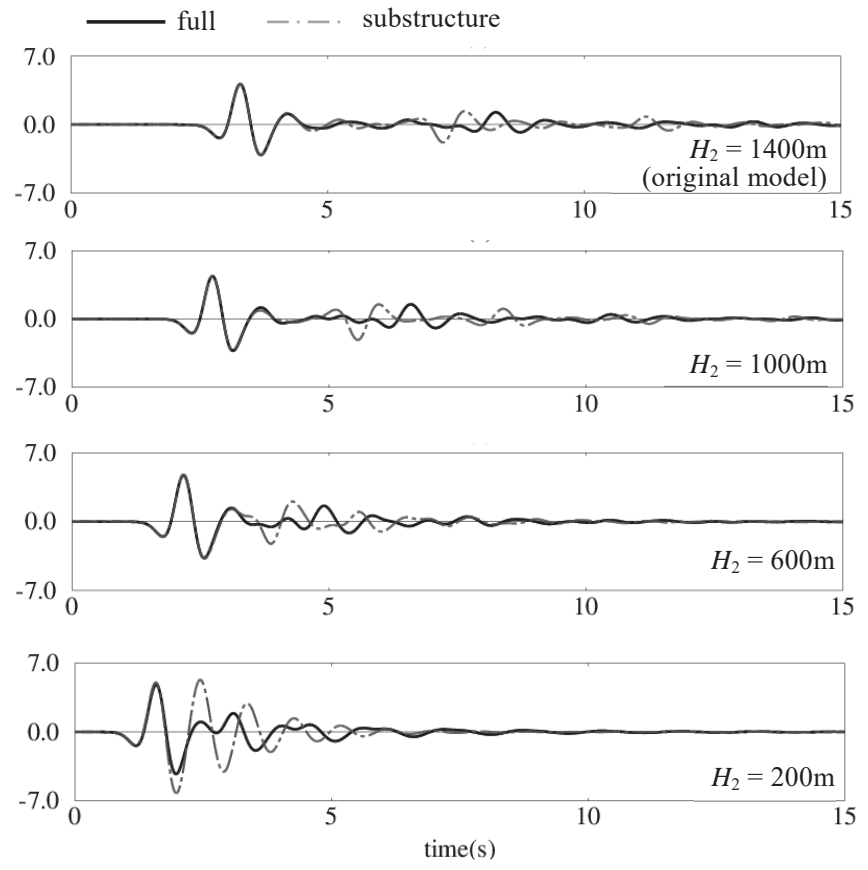

Fig. 3 Comparison of synthesized waveforms by full and substructure approaches for various thickness of deep subsurface structures. Ricker wavelet with fundamental period $1 \mathrm{~s}$ is used as an input motion.

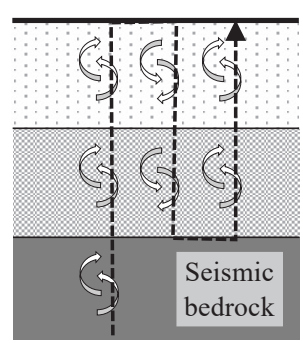

(a) Full method
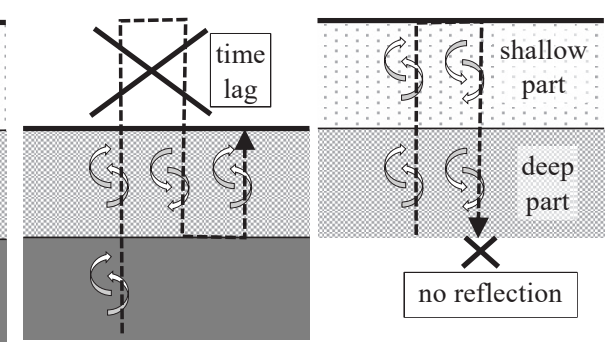

(b) Substructure method
Fig. 4 Images of transmitted and reflected waves in full and substructure methods and consequent errors. 
3 に示す。いずれも最初のパルス波については, 分離型と一体型で の差異は小さい。以降, これを直達波と呼ぶ。一方, 波形の後続部 では両者の差異が明確に現れる。この初動と後続波が現れる時間間 隔は, 地表から地震基盤までを $\mathrm{S}$ 波が一往復する時間に概ね等しい。 以降, これを基盤反射波と呼ぶ。深部地盤の層厚が薄いケースほど, 直達波と分離型解法で基盤反射波が現れるまでの時間がより短くな り，直達波と基盤反射波との干渉度合いが大きくなる。

分離型解法において, 地震動の計算誤差が生じる原因を, Fig. 4 に 整理する。同図(a)に示すように, 一体型解法では工学的基盤に入射 した地震波が地表面で反射して, 下降波が工学的基盤を透過する。 その後, 深部地盤の堆積層や地震基盤との層境界で反射し, その波 動が再度浅部地盤に入射する。一方，同図(b)に示すように，分離型 解法で得られる工学的基盤波の基盤反射波には, 工学的基盤と地表 間を往復する波動の伝播時間が考慮されていない。また浅部地盤で 地表から反射し深部地盤に伝わる地震波については，地震基盤等で

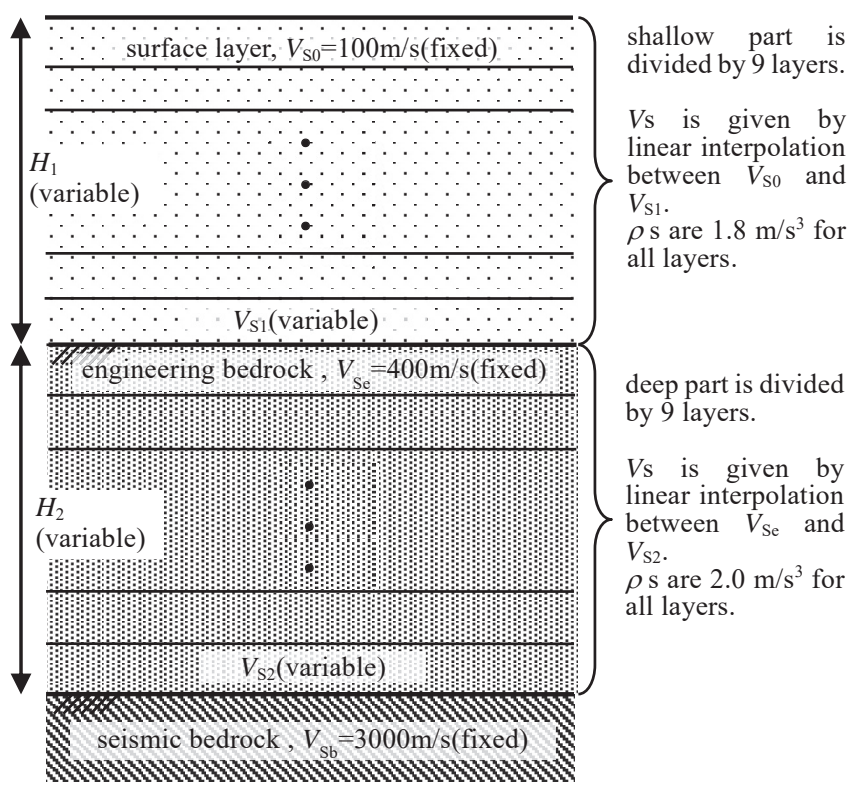

(a) Soil model

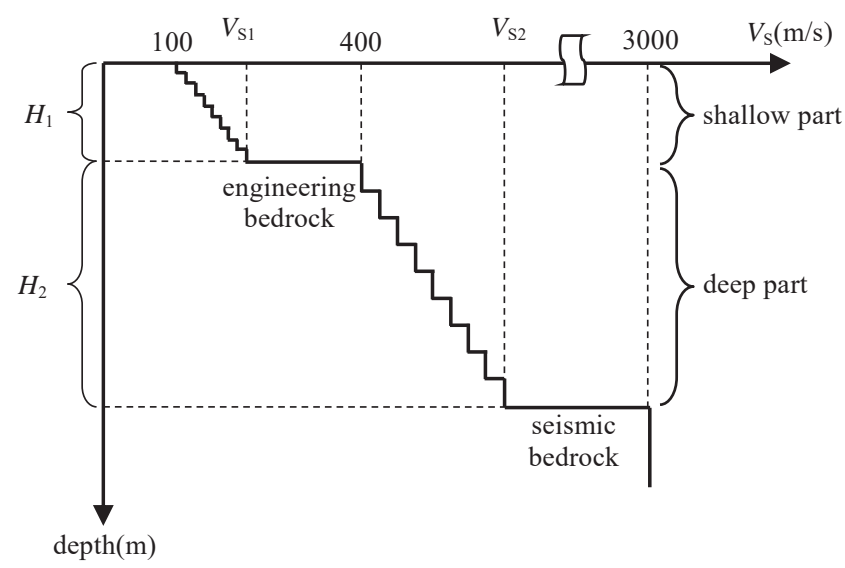

(b) S-wave profile for subsurface structure

Fig. 5 Soil model of horizontally flat layers for error estimation of substructure approach in parameter study.
発生する反射波の影響が考慮されない。これが直達波と基盤反射波 の到達時間に差が生じる等の原因となり, 両者の干渉度合いが変化 し, Fig. 2 で示した伝達関数のピーク振幅や振動数の変化を生じさ せることになる。

\section{3. パラメータ解析による分離型解法の計算誤差の評価}

\section{1 地盤モデルの設定}

基盤反射波の振幅や到達時間の差は，主に深部・浅部地盤の層厚 や地層境界での波動インピーダンス比に影響されることが想定され る。そこで, より汎用的な地盤モデルを用いて, 分離型解法による 計算誤差を調べる。対象とする地盤モデルを Fig. 5 に示す。最表層, 工学的基盤上面，地震基盤上面の $\mathrm{S}$ 波速度をそれぞれ $100 \mathrm{~m} / \mathrm{s} ， 400$ $\mathrm{m} / \mathrm{s}, \quad 3000 \mathrm{~m} / \mathrm{s}$ に固定し, 浅部地盤の層厚 $H_{1}$, 深部地盤の層厚 $\mathrm{H}_{2}$, 浅部地盤下部の $\mathrm{S}$ 波速度 $\mathrm{V}_{\mathrm{S} 1}$, 深部地盤下部の $\mathrm{S}$ 波速度 $\mathrm{V}_{\mathrm{S} 2}$ を変化さ せる。Table 2 に示寸 $\mathrm{H}_{1}, \mathrm{H}_{2}, \mathrm{~V}_{\mathrm{S} 1}, \mathrm{~V}_{\mathrm{S} 2}$ を基本ケースとする。本検討 では 4 変数のうち 3 変数を固定し, 残る 1 変数を同表に示寸範囲で 変化させる。浅部地盤と工学的基盤以下の深部地盤はそれぞれ 9 層 に等分割し, 中間部の $\mathrm{S}$ 波速度は線形で変化させた。密度は簡単に 浅部, 深部地盤内でそれぞれ一定值とした。減衰定数は前章での検 討と同じとした。

\section{2 分離型解法による伝達関数の一例}

分離型解法および一体型解法によって計算した伝達関数の一例を Fig. 6 に示す。図(a)は基本ケースである。横軸の振動数は, 浅部地 盤の平均 $\mathrm{S}$ 波速度から求めた卓越振動数 $\mathrm{f}_{1}(\mathrm{~Hz})$ で規準化した。同図 には分離型解法, 一体型解法による結果のほか, 浅部地盤のみと深 部地盤のみの伝達関数を併せて示す。分離型解法では $\mathrm{f} / \mathrm{f}_{1}=1$ 前後で, 山谷のピークのずれが大きいことが分かる。図(b) は $\mathrm{H}_{1}, \mathrm{~V}_{\mathrm{S} 1}, \mathrm{~V}_{\mathrm{S} 2}$ を 固定し， $\mathrm{H}_{2}=200 \mathrm{~m}$ としたケースの結果である。Fig. 2 の $\mathrm{H}_{2}=200 \mathrm{~m}$ のケースと同様に, 最初の増幅ピークから卓越振動数, 増幅率とも に大きな差異が見られる。

Table 2 Variable parameters.

\begin{tabular}{|l|c|c|}
\hline \multicolumn{1}{|c|}{ variables } & base values & range \\
\hline $\begin{array}{l}\mathrm{H}_{1}(\mathrm{~m}): \text { thickness of shallow } \\
\text { part of subsurface layers }\end{array}$ & 30 & $10-130$ \\
\hline $\begin{array}{l}\mathrm{H}_{2}(\mathrm{~m}): \text { thickness of deep part } \\
\text { of subsurface layers }\end{array}$ & 1000 & $200-4000$ \\
\hline $\begin{array}{l}\mathrm{V}_{\mathrm{S} 1}(\mathrm{~m} / \mathrm{s}): \text { S-wave velocity of } \\
\text { bottom of shallow part }\end{array}$ & 250 & $200-350$ \\
\hline $\begin{array}{l}\mathrm{V}_{\mathrm{S} 2}(\mathrm{~m} / \mathrm{s}): \text { S-wave velocity of } \\
\text { bottom of deep part }\end{array}$ & 1600 & $800-2600$ \\
\hline
\end{tabular}



(a) basic case

(b) $\mathrm{H}_{2}=200$ (m)

Fig. 6 Comparison of transfer functions of substructure method with rigorous full method. 


\section{3 パラメータ解析による伝達関数の計算誤差の把握}

伝達関数の計算誤差を定量的に評価するために, 伝達関数の実部 と虚部の差異を用いた次式の FDE 指標 ${ }^{14)}$ を利用する。

$$
\mathrm{FDE}=\sum_{i}^{N} \frac{\sqrt{\left(R_{1}-R_{2}\right)^{2}+\left(I_{1}-I_{2}\right)^{2}}}{\sqrt{R_{1}^{2}+I_{1}^{2}}+\sqrt{R_{2}^{2}+I_{2}^{2}}}
$$

ここで， $R, I$ は伝達関数の実部，虚部であり，下添え字 1,2 はそれ ぞれ一体型, 分離型解法の結果であることを示す。FDE 指標は, 複 素数で表現される 2 つのデータ間の誤差を $0 \sim 1$ までの数值で示す 指標であり，0 亿近いほど 2 つ誤差が小さい。FDE 指標の計算範 囲を $\mathrm{f} / \mathrm{f}_{1}=0.1 \sim 10$ とした。Fig. 6(a)に示した基本ケースの FDE 指 標は 0.13 である。

4 変数 $\mathrm{H}_{1}, \mathrm{H}_{2}, \mathrm{~V}_{\mathrm{S} 1}, \mathrm{~V}_{\mathrm{S} 2}$ のうち 3 変数を固定し, 残る 1 変数を変 化させたときの分離型解法の FDE 指標を Fig. 7 に示す。

浅部地盤の層厚 $\mathrm{H}_{1}$ が厚くなるほど，また深部地盤の層厚 $\mathrm{H}_{2}$ が薄 くなるほど，分離型解法の計算誤差が大きくなる。Fig. 4(b)で説明し たように, 分離型解法では工学的基盤から浅部地盤内を通り地表面 を往復する波動の伝播時間が無視されることになる。 $\mathrm{H}_{1}$ が厚いケー スではこの伝播時間が大きくなり， $\mathrm{H}_{2}$ が薄いケースでは深部地盤を 経由する反射波の伝播時間が短くなるほど，浅部地盤内の伝播時間 の差が大きく影響する。さらに, $\mathrm{H}_{2}$ が薄くなるにつれて, Fig. 3 に 示寸直達波と地震基盤からの反射波との時間間隔が短くなり, 両者 が干渉しや寸くなることから, Fig.6(b)に示寸伝達関数の最初の増幅 ピークから大きな差異が生じる。

$\mathrm{V}_{\mathrm{S} 1}$ の変化は, 分離型解法の計算精度に影響しない。これは工学的 基盤から地表面への波動伝播時間が長くなる効果と, 浅部地盤から 深部地盤への波動透過が小さくなる効果が相殺することによるもの と推察される。 $\mathrm{V}_{\mathrm{S} 2}$ が小さい場合, 寸なわち地震基盤境界でインピー



Fig. 7 FDE index between substructure and full methods for various parameters by fixing other 3 parameters.

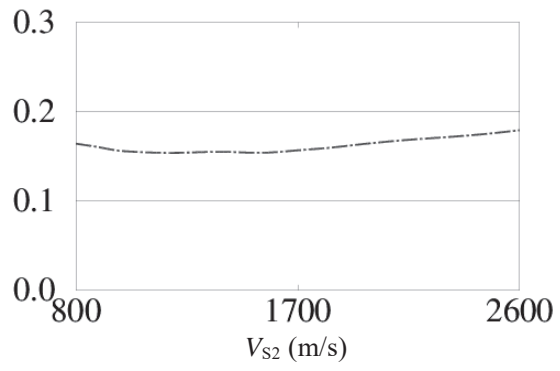

Fig. 8 FDE index between substructure and full methods for various $V_{\mathrm{S} 2}$ by fixing other 3 parameters when deep part is divided by 3 layers instead of 9 layers.
ダンス比が明瞭であるケースでは，計算誤差が大きく現れる傾向が 見られる。これはFig. 4 に示すように, 地表で反射し地震基盤との 境界で反射し, 再び地表に現れる波動の影響が大きい。関東平野の 中心部における堆積地盤のように深部地盤が厚く, 地震基盤と直上 の堆積層で $\mathrm{S}$ 波速度の変化が比較的小さい場合は, 分離型解法によ る誤差の影響は小さいと言える。

先に示した Fig. 2 のケースの FDE 指標は, $\mathrm{H}_{2}=1400 \mathrm{~m}$ のケース で $0.24, \mathrm{H}_{2}=200 \mathrm{~m}$ のケースで 0.33 とかなり大きくなっている。こ れを Fig. 7 と対応させると, 浅部地盤が $60 \mathrm{~m}$ と厚いこと, 地震基盤 と深部地盤の $V_{\mathrm{S}}$ のコントラストが大きいことによるものと考えら れる。大阪平野のように地震基盤と深部地盤の $V_{\mathrm{S}}$ のコントラストが 大きく, 特に基盤深度が浅い地域については, 分離型解法と一体型 解法の違いが比較的大きく現れるケースとなる。

中間層で不連続面のある地盤を想定したケースの一例として, Fig. 7 の $V_{\mathrm{S} 2}$ をパラメータとし, 深部地盤を 3 層で分割したときの FDE 指標を Fig. 8 に示す。 $V_{\mathrm{S} 2}=800 \mathrm{~m} / \mathrm{s}$ のときは 9 層で分割した場合との 誤差の変化は小さいが， $V_{\mathrm{S} 2}$ による変化は 9 層ほどの違いは見られ ず, $V_{\mathrm{S} 2}=2600 \mathrm{~m} / \mathrm{s}$ では $\mathrm{V}_{\mathrm{S} 2}=800 \mathrm{~m} / \mathrm{s}$ の FDE 指標を上回る。この原因 として， $V_{\mathrm{S} 2}$ が大きいほど粗い分割に起因する不連続面の $\mathrm{V}_{\mathrm{S}}$ のコン トラストが大きくなり，地震基盤からの反射波が低減する効果と不 連続面での反射波が発生する効果が相殺されたものと推定される。 深部地盤の中間部で不連続層がある場合については, 不連続層の数, 波動インピーダンス比，層厚比等の組み合わせで誤差評価が複雑に なる。このようなケースでのより詳細な議論は今後の課題としたい。

\section{4. 速度合成積に基づく厳密解法とその検証}

\section{1 速度合成積に基づく時刻歴応答計算の厳密解法}

分離型解法における計算誤差は, 浅部地盤からの下降波が深部地 盤の層境界面等で反射し，再び浅部地盤に入射する成分を無視する ことに起因する。このような効果を分離型解法の浅部地盤下部の境 界条件として取り入れることできるように，地盤と建物の相互作用 問題等で用いられる動的サブストラクチャー法の考え方を適用寸る。 浅部地盤の非線形挙動が進行し, 最大せん断ひずみが数\%レベルに


そこで, 逐次非線形解析にも適用できるように, 時間領域で剛性型 の速度合成積を用いた計算方法例えば15)を利用する。

対象とする振動数まで波動が透過するように浅部地盤を層分割し それを多数のばね, 質点から構成される多質点系モデルで表現する。 ここで，浅部地盤を $\mathrm{N}-1$ 層に分割し，工学的基盤を第 $\mathrm{N}$ 層とする。 このときの 1 次元土柱の時間領域における運動方程式は, 次式で与 えられる。

$$
[M]\{\ddot{x}(t)\}+[C]\{\dot{x}(t)\}+\{P(t)\}+\left\{P^{*}(t)\right\}=-[M]\{1\} 2 \ddot{E}_{0}(t)
$$

ここで $[M],[C]$ はそれぞれ質量, 減衰マトリックスであり, $N$ 次正方 行列である。 $\{P(t)\}$ は各土柱の非線形特性を含む復元力である。 $2 \ddot{E}_{0}(t)$ は解放工学的基盤での地震動の加速度，\{1\}はすべての成分が 1 のベクトルである。 $\{x(t)\}$ は解放工学的基盤に対する相対変位べク トルである。 $\left\{P^{*}(t)\right\}$ は工学的基盤に相当する下部境界 N のみに生じ る反力 $p_{N}^{*}(t)$ を含むべクトルであり, 通常は半無限の工学的基盤によ るダッシュポット $\rho_{e} V_{S e}$ と最下層の相対速度の積 $\rho_{e} V_{S e} \dot{x}_{N}(t)$ で表され 
る。ここで, $\rho_{e}, V_{S e}$ はそれぞれ工学的基盤の密度, $\mathrm{S}$ 波速度であり, $\dot{x}_{N}(t)$ は工学的基盤上面位置での相対速度である。

ここで深部地盤からの反力の正解值 $p_{N}^{*}(t)$ を求めるため, 最初に Fig. 9 に示す工学的基盤面以深の深部地盤の動的インピーダンス $s_{N}(\omega)$ を振動数領域で求める。ここで $\omega$ は円振動数である。重複反射 理論に基づく $\mathrm{j}$ 層の剛性マトリクス $[s(\omega)]_{j}$ は以下となる。

$[s(\omega)]_{j}$

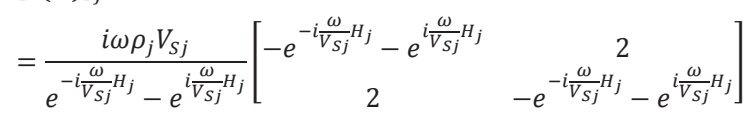

ここで， $\rho_{j}, V_{S j}$ はそれぞれ $\mathrm{j}$ 層の密度, $\mathrm{S}$ 波速度， $i=\sqrt{-1}$ である。 各層の剛性マトリクス $[s(\omega)]_{j}$ および地震基盤の動的インピーダン ス $i \omega \rho_{B} V_{S B}$ を重祆合わせ, 深部地盤の全体剛性マトリクス $[S(\omega)]$ を計 算する。工学的基盤面での水平外力と水平変位との関係から, 当該 位置での動的インピーダンス $s_{N}(\omega)$ は $[S(\omega)]^{-1}$ の第 $(1,1)$ 要素の逆数 となる。

$s_{N}(\omega)$ は振動数依存性を有するので, 時間領域では $x_{N}(t)$ との合成 積で評価する必要がある。ここでは計算精度を考慮し, 速度合成積 を採用し， $s_{N}(\omega) /(i \omega)$ を工学的基盤でのダッシュポットに相当する 特異項 $s_{N I}=\rho_{e} V_{S e}$ と正則項 $s_{N R}(\omega)=s_{N}(\omega) /(i \omega)-\rho_{e} V_{S e}$ に分離して 表現する。このとき $p_{N}^{*}(t)$ は以下のように表現される。

$$
p_{N}^{*}(t)=\rho_{e} V_{S e} \dot{x}_{N}(t)+\int_{0}^{t} s_{N R}(t-\tau) \dot{x}_{N}(\tau) d \tau
$$

ここで $s_{N R}(t)$ は $s_{N R}(\omega)$ を逆フーリエ変換したインパルス応答である。 速度合成積の評価法はいくつかある ${ }^{15)}$ が，ここでは各ステップで 直接積分により評価し, 式(2)の時刻歴応答解析に適用寸る。時間領 域となっている式(2)を Newmark- $\beta$ 法で離散化し, 式(4)右第 1 項目 の特異項は陰解項として, 速度合成積を含む第 2 項目の正則項は補 正外力項として評価する。

\section{2 速度合成積に基づく厳密解法の検証}

速度合成積に基づく厳密解法を, Table 1 に示した例題で検証する。 ここでは計算誤差が最も大きく現れる, $\mathrm{H}_{2}=200 \mathrm{~m}$ のケースを対象 とする。

Fig. 10 に, 工学的基盤より深部の地盤構造による速度インパルス 応答関数を示す。インパルス応答関数は, 工学的基盤以下からの反 射波の影響を表現した動的インピーダンス関数を時間領域で表現し たものに相当する。 0 秒地点に見られる振幅は, 工学的基盤以下を

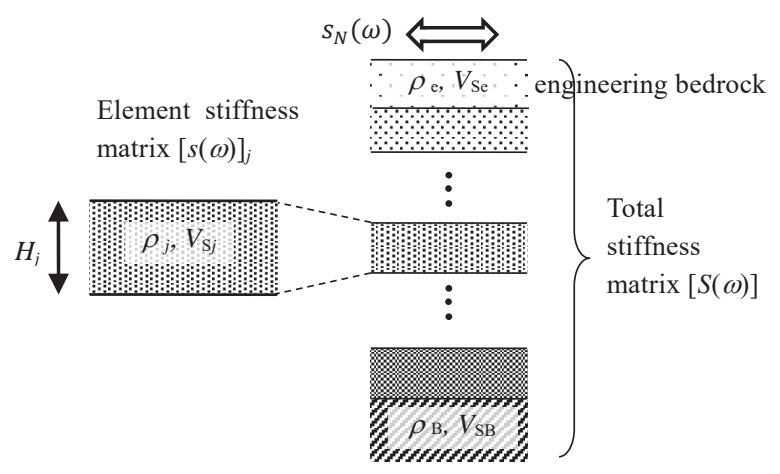

Fig. 9 Deep part of soil model from seismic bedrock to engineering bedrock and setup of total stiffness matrix.
半無限均質地盤としたときの境界条件であるダッシュポット $\rho_{e} V_{S e}$ による減衰力を表現している。0 秒以降の波形の各山々が地震基盤 を含む工学的基盤以深からの反射波を表現している。これが従来の 分離型解法での計算誤差を生じさせる原因となる。

このインパルス応答関数と工学的基盤面での相対速度応答波形と の合成積を，浅部地盤の応答解析で外力として組み込む。時刻歴応 答解析では深部地盤は線形とし，浅部地盤を線形としたケースと， 非線形としたケースの両方について行う。非線形としたケースでは 浅部地盤の非線形パラメータを，簡単に基準せん断ひずみ $\gamma_{0.5}=$ $0.18 \%$, 最大減衰定数 $\mathrm{h}_{\max }=17 \%$ とした HD モデル ${ }^{16)}$ で与え, 逐次 非線形解析を行う。入射波としてリッカー波の代わりに，中央防災 会議による上町断層帯の想定地震動 ${ }^{17)}$ を逆算して求めた地震基盤波

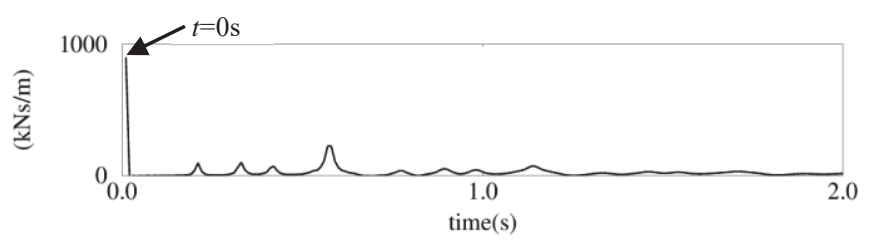

Fig. 10 Velocity impulse response function at outcropped engineering bedrock $(H=200 \mathrm{~m})$.

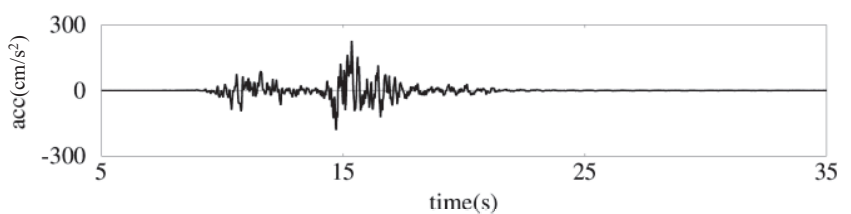

(a) Input motion
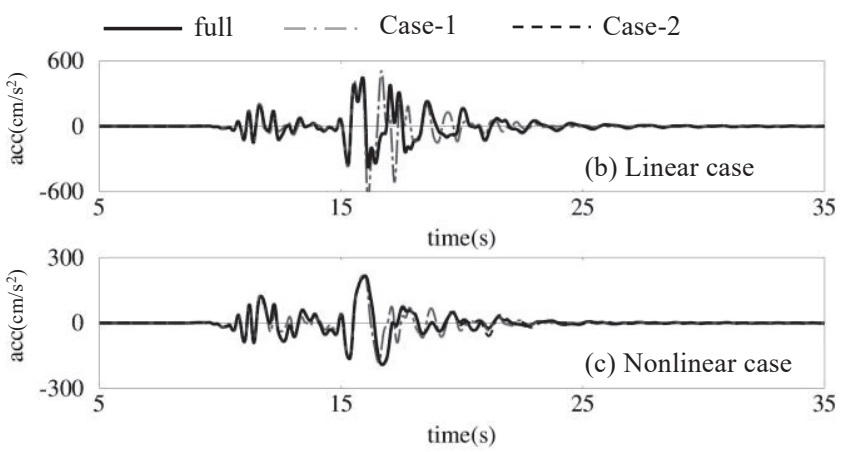

Fig. 11 Acceleration time histories of input motions and on ground surface for cases of linear and nonlinear soil responses.

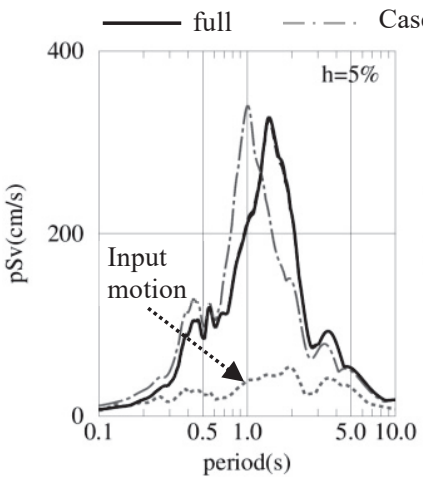

(a) Linear case

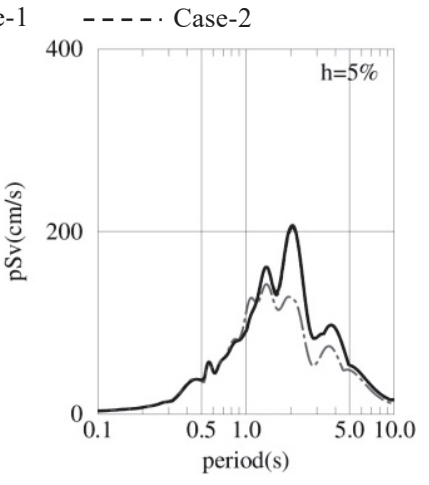

(b) Nonlinear case
Fig. 12 Comparison of response spectra on ground surface for cases of linear and nonlinear soil responses. 


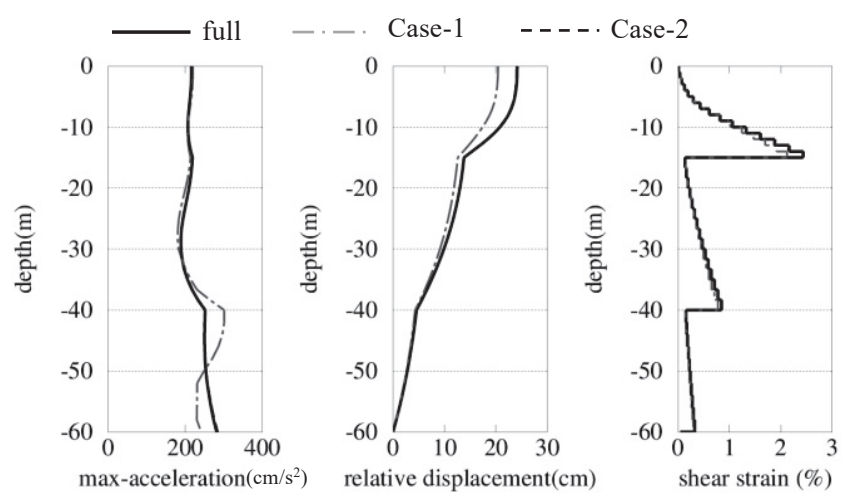

Fig. 13 Depth-wise distribution of maximum soil responses.

13)を用いる。ただし, そのままのレベルでは浅部地盤の最大応答せ ん断ひずみが大きすぎるため,ここでは振幅を $1 / 2$ に調整した。

入力に用いた地震基盤波の加速度波形を Fig. 11(a)に, その擬似速 度応答スペクトル pSv ( $h=5 \%)$ を Fig. 12(a)に示す。このとき地表面で 得られた加速度応答波形を Fig. 11(b)(c)に, pSv ( $(\mathrm{h}=5 \%$ )を Fig. 12(a)(b) に示す。図中の Case-1 は従来の分離型解法による解析結果であり, Case-2 は速度合成積を用いた修正法による解析結果である。また非 線形解析により得られた地盤の最大応答分布を Fig.13に示す。

浅部地盤を線形とした Fig. 11(b)の加速度波形について, 従来の分 離型解法である Case-1 では $\mathrm{t}=16 \mathrm{~s}$ 以降で一体型解法と差異が大き く現れるが，改良法である Case-2 は一致する。

浅部地盤を非線形とした Fig. 11(c)では, Case-1 と一体型解法との 差異は小さくなる。これは, 浅部地盤の非線形挙動による履歴減衰 が大きくなることから, 浅部地盤から深部地盤一透過する波動成分 が少なくなることが一因と考えられる。それでも， $\mathrm{t}=16 \mathrm{~s}$ 以降で一 体型解法とのずれが見られるが, 改良法である Case-2 は一体型解法 と波形がほぼ一致する。これらの傾向は Fig. 12(b)の pSv(h=5\%), Fig. 13 の地盤の最大応答分布でも同様である。浅部地盤では非常に強い 非線形挙動を呈しているが, 改良法を用いることにより浅部地盤と 深部地盤の連成効果を考慮した厳密解を得ることができる。従来の 分離型解法では, 正解值に比べせん断ひずみ等がやや過小評価され ている。

\section{5. まとめ}

本研究では, 地震動の地盤増幅を評価する際に慣用的に用いられ る深部地盤と浅部地盤を別々に解く分離型解法について, 浅部, 深 部地盤の厚さやインピーダンス比等を変化させ, 一体型解法との比 較を通じ計算精度を評価した。次に, 浅部地盤の応答解析で深部地 盤との連成効果を取り入れた厳密解として, 底面境界部で深部地盤 の影響を速度合成積を用いて評価する分離型解法を提示し, その計 算精度を検証した。以下に得られた知見をまとめる。

(1) 従来用いられている分離型解法では, 浅部地盤から深部地盤 に透過し, 地震基盤等で発生する反射波の影響が考慮されな い。このため, 浅部地盤分だけの波動の到達時間に差が現れ, 直達波と基盤反射波の到達時間に差が生じる等の原因となる。 これにより, 両者の干渉度合いが変化し, 伝達関数のピーク振 幅や振動数が変化し, 一体型解法での地盤増幅特性と差異が
現れる。

(2) パラメータ解析により分離型解法の計算誤差を評価した結果, 浅部地盤の層厚が厚いほど, 精算解である一体型解法との差 異が大きくなる。また深部地盤の層厚が薄いほど, また地震基 盤上面位置で $\mathrm{S}$ 波速度比が大きいほど計算誤差が大きくなる。 例えば, 大阪平野のように地震基盤と深部地盤の $\mathrm{S}$ 波速度の コントラストが大きく, 特に基盤深度が浅い地域については, 分離型解法と一体型解法の違いが大きく現れる。一方, 関東平 野の中心部における堆積地盤のように深部地盤が厚く, 地震 基盤と直上の堆積層で $\mathrm{S}$ 波速度の変化が比較的小さい場合は, 分離型解法による誤差の影響は小さい。

(3) 分離型解法でモデル底面に深部地盤の影響を加味した境界条 件を付与し, 従来の粘性境界に加え, 基盤反射波の影響を相対 速度との合成積で評価する改良法を示した。この方法により 浅部地盤が線形だけではなく, 非線形となる場合でも, 一体型 解法による結果と一致し, 分離型解法での厳密解が得られる ことを示した。

\section{謝辞}

本論文を作成するに当たり, 東京理科大学卒論生である中村亮輔 氏，石塚尚美氏の修士，卒業論文と発表論文を参考にさせていただ きました。石塚尚美氏には, 計算の他, 本論文の原稿, 図の作成に 協力いただきました。中央防災会議から公開されている地震波デー 夕を利用させていただきました。2 名の査読者によるコメントは論 文を改善する上で大変役立ちました。

\section{参考文献}

1) 久田嘉章・他：強震動予測手法に関するベンチマークテスト：理論的手 法の場合 その 1 , 日本建築学会技術報告集, 第 35 号, pp.43-48, 2011.2

2）永野正行：表層地盤増幅と実効入力動（その 1）地盤増幅の立場から, pp.49-54, シンポジウム 阪神・淡路大震災を振り返り, 来たる大地震に 備える一建築振動研究に課せられたもの一日本建築学会構造委員会振動 運営委員会, 2011.3.7

3) 肥田剛典, 永野正行 : 2011 年東北地方太平洋沖地震時における強震記録 とアンケート調查に基づく超高層集合住宅の応答の推定, 日本建築学会 構造系論文集，第 78 巻，第 683 号, pp.51-60, 2013.1

4) 永野正行, 肥田剛典, 田沼毅彦, 渡辺一弘, 井川望, 伊藤真二 : 2011 年 東北地方太平洋沖地震時の東京湾沿岸部に㧍ける基盤波推定と長周期地 震動の地盤增幅特性, 日本建築学会技術報告集, 第 19 巻, 第 43 号, pp.849854, 2013.10

5) Schnabel, P. B., Lysmer, J. and Seed, H. B. : 'SHAKE' A Computer Program for Earthquake Response Analysis of Horizontally Layered Sites, EERC 72-12, College of Eng. University of California Berkeley, California, 1972

6) 吉田望, 篠原秀明, 澤田純男, 中村晋 : 設計用地震動の設定における工学 的基盤の意義, 土木学会地震工学論文集, 第 28 巻, $170,2005.8$

7) 佐藤智美 : 鉛直アレー観測記録の逆解析から評価される地盤材料物性, 第 32 回地盤震動シンポジウム, pp.41-50, 日本建築学会, 2005.1

8) 小林源裕, 儘田豊 : 表層の低速度層を考慮した地震動の簡易数值解析手 法の検討, 日本地震工学会論文集第 16 巻, 第 2 号, pp.40-63, 2016.2

9) 田中清和, 野畑有秀, 岡崎由佳 : ハイブリッド法強震動予測における解 放工学的基盤波の算定法についての検討, 日本建築学会大会学術講演梗 概集, 構造 II, pp.317-318, 2014.9

10) 永野正行, 工藤一嘉, 武村雅之: 神戸市長田区における地下構造の不整 形性を考慮した 1995 年兵庫県南部地震 $(\mathrm{MJ}=7.2)$ の余震アレイ観測記録の シミュレーション解析, 地震第 2 輯第 52 卷, pp. 25-41, 1999

11) 永野正行, 大野 晋, 菊地利喜郎, 小林啓美: 深層アレー観測記録のシミ ユレーション解析と基盤の不整形性の影響, 日本建築学会構造系論文集, 
第 570 号, pp.45-52, 2003.8

12) 翠川三郎：地震断層を考慮した地震動スペクトルの推定手法と適用例, 昭和 63 年理工学振興会セミナー, 震源域での地震動強さの予測, pp.2534, 1988

13) 永野正行, 東山恵: 深部地盤の地中段差近傍における地震動増幅特性, 日本建築学会構造系論文集, 第 7 巻, 第 643 号, pp.1585-1594, 2009.9

14) Dragovich, Jeff J. and Lepage, A.: FDE Index for Goodness-of-Fit Between Measured and Calculated Response Signals, Earthquake Engng. Struct. Dyn., pp.1751-1758, 2009.9

15) 源栄正人, 永野正行 : 非線形構造物と地盤の動的相互作用問題における コンボリューション積分の再帰的評価法とその応用, 日本建築学会, 応 用力学シリーズ 3, pp.79-132, 1996.2

16) 古山田耕司, 宮本裕司, 三浦賢治：多地点での原位置採取試料から評価 した表層地盤の非線形特性, 第 38 回地盤工学会研究発表会, pp.2077-2078, 2003.7

17) 中央防災会議 : 東南海, 南海地震に関する専門調査会（第 26 回）, 中部 圈・近畿圈の内陸地震の震度分布等について, 資料（平成 18 年 12 月 7 日) , 2006 .

18) 中村亮輔, 永野正行: 表層地盤の地震動増幅の評価誤差と速度合成積を 用いた修正法の提案, 日本建築学会関東支部研究報告集, pp.329-332, 2012.3

19) 中村亮輔, 永野正行 : 表層地盤の分離解析による地震動の評価精度の検 討, 日本建築学会大会学術講演梗概集, 構造 II, pp.123-124, 2012.9 


\title{
EFFECTS OF DEEP SUBSURFACE STRUCTURE ON GROUND MOTION AMPLIFICATION IN SHALLOW SUBSURFACE STRUCTURE AND VERIFICATION OF AN IMPROVED NUMERICAL METHOD BASED ON THE SUBSTRUCTURE METHOD
}

\author{
Masayuki NAGANO* \\ ${ }^{*}$ Prof., Dept. of Architecture, Faculty of Science and Technology, Tokyo University of Science, Dr.Eng.
}

Site amplification is one of the most important factors in strong ground motion prediction at construction sites. In ground motion calculation methods such as the stochastic Green's function method, seismic motions are first synthesized on an outcrop of engineering bedrock with an S-wave velocity of more than $400 \mathrm{~m} / \mathrm{s}$. Ground motions on the ground surface are then evaluated using the substructure method by independently modeling only the shallow part of the subsurface structure, using ground motions on the outcropped engineering bedrock as input motions. This approach sometimes yields inaccurate results because the coupling effect between the shallow and deep parts of the subsurface structure is ignored.

In the present study, the calculation accuracy of the conventional substructure method is first investigated for various soil layers. A rigorous method that incorporates the coupling effect with the deep subsurface structure is then proposed based on the nonlinear substructure method in terms of velocity convolution integrals.

As an example, synthesized surface motions calculated by the conventional substructure method and a full rigorous analysis are compared using the $\mathrm{S}$-wave structure of the Osaka Plain, where the $\mathrm{S}$-wave velocity between the seismic bedrock and overlying sediments varies abruptly, for deep soil layers of various thicknesses. Although the onset Swave parts coincide for both methods, differences in the later phase of the waveforms are observed. These differences occur because the reflected waves from seismic bedrock transmitted from the shallow layer to the deep layer are essentially ignored in the conventional substructure method.

Next, generalized soil models are used to assess errors in the conventional substructure method by varying three and fixing one of the following four parameters: the S-wave velocity just above the seismic bedrock, the S-wave velocity just above the engineering bedrock, and the thicknesses of the shallow and deep parts of the soil. The error index, FDE, is used to quantify the calculation accuracy of the conventional substructure method. The error becomes large when the thickness of the deep soil is small and the thickness of the shallow soil is large, due to the difference in the travel time of the waves reflected from the boundary of the seismic bedrock. The impedance ratio between the seismic rock and sediments also contributes to the error.

In order to rigorously incorporate the coupling effect of the deep and shallow soil layers into the conventional substructure method, a frequency-dependent dynamic impedance function is added to the bottom layer, instead of the viscous boundary for the engineering bedrock. First, the dynamic impedance function on an outcrop of engineering bedrock that includes the deep part of the soil is calculated in the frequency domain. The nonlinear behavior of the shallow soil layer requires a seismic response analysis in the time domain. The frequency-dependent dynamic impedance function for the deep soil layer is converted into a time-domain impulse response, which is used in the convolution integral of the velocity in the time-domain analysis.

The proposed method is applied to the ground motion evaluation using the subsurface structure of the Osaka Plain. The acceleration response time histories and the response spectra obtained by the proposed method coincide well with those obtained through a full rigorous analysis. In the case of the nonlinear analysis, the coupling effect decreases because of the hysteretic damping effects of the shallow soil. However, the results obtained using the proposed method have been verified to approximately coincide with those obtained through the full rigorous analysis, implying that the proposed method provides a rigorous solution that considers the coupling effect with the deep part of the subsurface structure. 